\title{
Vaccinated C57BL/6 Mice Develop Protective and Memory T Cell Responses to Coccidioides posadasii Infection in the Absence of Interleukin-10
}

\author{
Chiung-Yu Hung, Natalia Castro-Lopez, Garry T. Cole \\ Department of Biology and South Texas Center for Emerging Infectious Diseases, University of Texas, San Antonio, Texas, USA
}

\begin{abstract}
High concentrations of lung tissue-associated interleukin-10 (IL-10), an anti-inflammatory and immunosuppressive cytokine, correlate with susceptibility of mice to Coccidioides spp. infection. In this study, we found that macrophages, dendritic cells, neutrophils, and both $\mathrm{CD}^{+}$and $\mathrm{CD}^{+}$T cells recruited to Coccidioides posadasii-infected lungs of nonvaccinated and vaccinated mice contributed to the production of IL-10. The major IL-10-producing leukocytes were CD8 ${ }^{+} \mathrm{T}$ cells, neutrophils, and macrophages in lungs of nonvaccinated mice, while both Foxp $3^{+}$and Foxp $3^{-}$subsets of IL- $10^{+} \mathrm{CD}^{+}$T cells were significantly elevated in vaccinated mice. Profiles

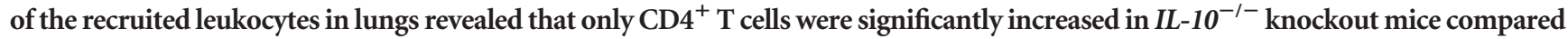
to their wild-type counterparts. Furthermore, ex vivo recall assays showed that $\mathrm{CD}^{+}{ }^{+} \mathrm{T}$ cells isolated from vaccinated $I L-10^{-/-}$mice compared to vaccinated wild-type mice produced significantly higher amounts of IL-2, gamma interferon (IFN- $\gamma$ ), IL-4, IL-6, and IL17A in the presence of a coccidioidal antigen, indicating that IL-10 suppresses Th1, Th2, and Th17 immunity to Coccidioides infection. Analysis of absolute numbers of $\mathrm{CD}_{4}{ }^{+} \mathrm{CD}_{2} \mathrm{~L}^{-} \mathrm{CD}^{+}{ }^{+} \mathrm{T}$ effector memory $\mathrm{T}$ cells $\left(\mathrm{T}_{\mathrm{EM}}\right)$ and IFN- $\gamma$ - and IL-17A-producing CD4 ${ }^{+} \mathrm{T}$ cells in the lungs of Coccidioides-infected mice correlated with better fungal clearance in nonvaccinated $I L-10^{-/-}$mice than in nonvaccinated wild-type mice. Our results suggest that IL-10 suppresses $\mathrm{CD} 4^{+}$T-cell immunity in nonvaccinated mice during Coccidioides infection but does not impede the development of a memory response nor exacerbate immunopathology of vaccinated mice over at least a 4-month period after the last immunization.
\end{abstract}

\footnotetext{
occidioides is a fungal pathogen and the causative agent of a

human respiratory disease known as coccidioidomycosis, or San Joaquin Valley fever (1). Human infections typically occur by inhalation of spores (arthroconidia) released into the air from the saprobic phase of the soilborne fungus. In the approximately $40 \%$ of human exposures that result in symptomatic infection, the initial clinical manifestation is characterized by onset of an acute respiratory response that can occur within 1 to 3 weeks after inhalation of the pathogen. In a few patients $(<5 \%)$, Coccidioides species infections may progress to life-threatening, chronic pneumonia, extrapulmonary nonmeningeal disease, or meningitis. The latter is the most feared complication of coccidioidomycosis (1). The number of reported cases of primary coccidioidal pneumonia in Arizona and California has significantly increased during the last decade (2), which has raised the level of awareness among people who live in regions where this mycosis is endemic. Development of a vaccine and effective therapeutic strategies against coccidioidomycosis would promote the well-being of atrisk populations in the areas of endemicity.

Interleukin-10 (IL-10) is a pleiotropic cytokine with anti-inflammatory and immunosuppressive functions and the ability to impact both innate and adaptive immunity to microbial infections (3-5). Studies using IL-10 knockout mice have suggested that this cytokine is an essential immune regulator in a variety of fungal infections, including infections caused by Candida spp. (6), Cryptococcus neoformans (7), Histoplasma capsulatum (8), Pneumocystis carinii (9), and Aspergillus fumigatus (10). A correlation has been revealed between susceptibility to Coccidioides infection and the amount of IL-10 produced (11-14). Loss of IL-10 production significantly improves the outcome of coccidioidomycosis in nonvaccinated mice $(12,13)$. IL-10 can exert direct inhibition on $\mathrm{CD}^{+}{ }^{+} \mathrm{T}$ cell proliferation and cytokine synthesis (15). In the latter
}

case, IL-10 has been shown to suppress the production of IL-2, gamma interferon (IFN- $\gamma$ ), IL-4, and IL-5 (16) and, thereby, hamper protective responses of both Th1 and Th2 cells during early stages of microbial and viral infections $(15,17)$. Recently, IL-10 has also been shown to inhibit murine macrophages and T cells in the secretion of Th17-related cytokines (18). The latter are required for development of Th17-type immunity, which is essential for vaccine-induced protection against Coccidioides infection and other dimorphic fungal diseases $(19,20)$. Thus, treatment with anti-IL-10 antibody and vaccination strategies aimed at neutralizing excess IL-10 following microbial infection should provide therapeutic advantages $(21,22)$.

On the other hand, IL-10 is required to control fungal infections caused by Candida albicans and P. carinii $(9,23)$ as well as numerous viral, bacterial, and parasitic pathogens (24-26). Although IL-10-deficient mice infected with Candida revealed significantly reduced fungal burden, the mice presented with severe inflammatory pathology and susceptibility to reinfection (23). An attempt to treat Leishmania major infection in mice by immunization with an IL-10 peptide-based vaccine revealed increased parasitic burden and exacerbated disease (27). These contradictory effects of IL-10 raise concerns about application of supple-

\footnotetext{
Received 11 September 2013 Returned for modification 2 October 2013 Accepted 3 December 2013

Published ahead of print 9 December 2013

Editor: G. S. Deepe, Jr.

Address correspondence to Chiung-Yu Hung, Chiungyu.Hung@utsa.edu. Copyright @ 2014, American Society for Microbiology. All Rights Reserved. doi:10.1128/IAl.01148-13
} 
mental IL-10 therapy to treat inflammatory diseases or neutralization of IL-10 to improve the efficacy of vaccines against microbial infections $(21,22)$.

Despite the considerable information available regarding the regulatory functions of IL-10 for the immune response and in immunopathology, there is less known about the major sources of this cytokine during specific microbial infections. IL-10 can be produced by $\mathrm{CD}^{+} \mathrm{T}$ regulatory (Treg) cells, $\mathrm{CD}^{+} \mathrm{T}$ cells, and numerous members of the innate immune repertoire, including dendritic cells (DCs), macrophages, mast cells, natural killer cells, neutrophils (polymorphonuclear leukocytes [PMNs]), and $\mathrm{B}$ cells (3). In a murine model of acute brucellosis, CD $4^{+} \mathrm{CD} 25^{+} \mathrm{T}$ cells were identified as the major source of IL-10 (28). These cells were shown to play an important role in modulating the early immune response to Brucella abortus infection. Similarly, T-cellderived, but not B-cell-derived, IL-10 was reported to contribute to the suppression of the antigen-specific $\mathrm{CD} 4{ }^{+} \mathrm{T}$-cell response to a helminth parasite infection in mice (29). In the case of Yersinia enterocolitica infection, the main sources of IL-10 were neutrophils (30). In this study, we explored the following questions related to the IL-10 response to Coccidioides posadasii infection. (i) What are the cellular sources of IL-10 in vaccinated versus nonvaccinated C57BL/6 mice following pulmonary infection? (ii) Are the composition and numbers of immune cells in the lungs of Coccidioides-infected mice altered in the absence of IL-10? (iii) Can IL-10-deficient mice develop long-term T-cell immunity and polarization of the $\mathrm{CD}^{+}{ }^{+} \mathrm{T}$-cell response to infection? (iv) Does ablation of IL-10 cause immunopathology during early stages of coccidioidomycosis?

\section{MATERIALS AND METHODS}

Fungal strain, growth conditions, and spore preparation. The virulent fungal strain used to challenge mice in this study was clinical isolate C735 of Coccidioides posadasii. A previously described genetically engineered, live, attenuated mutant strain $(\Delta c t s 2 / a r d 1 / c t s 3)$ derived from the parental C735 isolate was employed as a vaccine and designated $\Delta \mathrm{T}(19,31)$. The saprobic phases of both the wild-type (WT) and mutant strains were grown on GYE agar ( $1 \%$ glucose, $0.5 \%$ yeast extract, $1.5 \%$ agar) for 3 to 4 weeks at $30^{\circ} \mathrm{C}$ to generate a confluent layer of spores on the surface of the solid culture medium. Spore suspensions used for vaccination or intranasal challenge of mice as described below were prepared as previously reported (32). All culturing and preparatory procedures that involved live cells of $C$. posadasii were conducted in a biosafety level 3 (BSL3) laboratory.

Mouse strain. Breeder pairs of C57BL/6 and B6.129P2-IL10 $0^{\text {tm1Cgn }} / \mathrm{J}$ $\left(I L-10^{-1-}\right)$ mice were purchased from Jackson Laboratory. Mice were housed in a specific-pathogen-free (SPF) animal facility at the University of Texas at San Antonio (UTSA) and handled according to guidelines approved by the university's Institutional Animal Care and Use Committee. Both strains of mice were gender matched. Animals 8 to 10 weeks old with an average weight of 18 to $22 \mathrm{~g}$ were used in this study. Mice were relocated to an animal biosafety level 3 laboratory prior to vaccination and infection.

Vaccination protocol, animal challenge, and evaluation of protection. Primary immunization of C57BL/6 and $I L-10^{-/-}$mice with $5.0 \times$ $10^{4}$ viable spores of the live $\Delta \mathrm{T}$ vaccine in $100 \mu \mathrm{l}$ phosphate-buffered saline (PBS) was performed by the subcutaneous route in the abdominal region. This initial vaccination step was followed 14 days later with a boost of $2.5 \times 10^{4}$ spores by the same route of immunization. Control mice were injected with PBS following the same vaccination protocol as above. The animals were challenged 16 weeks after completion of the vaccination protocol by intranasal instillation with a suspension of approximately 80 viable spores of the virulent, parental isolate of C. posadasii (C735) in 35 $\mu l$ PBS as previously reported (31). The fungal burden in the lungs and spleen was determined at the time when the animal approached the moribund state or at 14 days postchallenge (DPC) by plating serial dilutions of separate lung and spleen homogenates on GYE agar containing $50 \mu \mathrm{g} / \mathrm{ml}$ chloramphenicol, as reported elsewhere (31). The number of CFU of Coccidioides was expressed on a log scale and reported for each group of 10 animals as previously described (31). Survival studies of vaccinated versus nonvaccinated mice were conducted over 60 days postchallenge as reported previously (31).

Cytokine assays. Concentrations of IL-10 in supernatants of lung homogenates were compared between nonvaccinated and $\Delta \mathrm{T}$-vaccinated mice sacrificed at 5, 7, 9, 11, and 14 DPC (4 animals per group). Lung homogenates of individual mice were prepared as previously described (33), supernatants were obtained by centrifugation $\left(8,000 \times g\right.$ at $4^{\circ} \mathrm{C}$ for 10 $\mathrm{min}$ ), and samples were stored at $-80^{\circ} \mathrm{C}$ until ready for analysis. Assays of cytokine and chemokine concentrations were conducted using a Bio-Plex suspension array system (Bio-Rad Laboratories, Hercules, CA) as previously reported (33).

Quantitative RT-PCR assays. Total RNA was extracted from isolated pulmonary cells of Coccidioides-infected lungs of nonvaccinated and vaccinated C57BL/6 mice (three animals per group) using an RNeasy kit (Qiagen, Valencia, CA). The samples were treated with DNase (Promega, San Luis Obispo, CA) to remove traces of contaminating DNA. Reverse transcription (RT) was performed using $5 \mu \mathrm{g}$ total RNA in a $50-\mu \mathrm{l}$ reaction mixture containing oligo $(\mathrm{dT})$ and SuperScript III (Invitrogen, Carlsbad, CA) according to the manufacturer's instructions. The relative amounts of specific gene transcripts encoding $I L-10$ and the forkhead box P3 transcription factor (Foxp3) (34) in the lungs of nonvaccinated and vaccinated mice were examined by quantitative RT-PCR (QRT-PCR) as previously reported (32). The data are presented as the mean fold change \pm the standard error of the mean (SEM).

Quantification of Treg cells. Regulatory T cells are characterized by expression of CD3, CD4, and CD25 surface markers as well as expression of the Foxp 3 transcription factor gene. Total pulmonary leukocytes were isolated from nonvaccinated mice or mice immunized with the $\Delta \mathrm{T}$ vaccine and sacrificed at 5 to 14 days postchallenge ( 3 mice per group) as previously reported (19). A standard methodology was employed for direct monoclonal antibody (MAb) labeling and enumeration of selected pulmonary leukocyte phenotypes by fluorescence-activated cell sorting (FACS) with a FACSCalibur flow cytometer (BD Biosciences, Franklin Lakes, NJ) as previously described (19). Isolated pulmonary leukocytes were blocked and labeled with fluorochrome-conjugated monoclonal antibodies against CD3 (clone 17A2), CD4 (clone RM4-5), and CD25 (clone PC61). The cells were then chemically fixed and permeabilized using a mouse Foxp3 buffer set (BD Bioscience) and incubated with $0.25 \mu \mathrm{g}$ of fluorochrome-conjugated anti-Foxp3 MAb (clone MF23) in $40 \mu \mathrm{l}$ of FACS buffer for $30 \mathrm{~min}$ at $4^{\circ} \mathrm{C}$. The absolute number of Treg cells was determined by multiplying the percentage of the gated population by the total number of $\mathrm{CD} 45^{+}$cells.

Characterization of IL-10-producing leukocyte subpopulations by flow cytometry. Pulmonary leukocytes were isolated from nonvaccinated mice or mice vaccinated with the $\Delta \mathrm{T}$ vaccine as well as naive (untreated) $I L-10^{-/-}$mice. The latter were used as negative controls for intracellular staining of IL-10. Pulmonary cells were stimulated with $50 \mathrm{ng} / \mathrm{ml}$ phorbol myristate acetate (PMA; Sigma-Aldrich, St. Louis, MO) and $500 \mathrm{ng} / \mathrm{ml}$ ionomycin (Sigma-Aldrich) in the presence of GolgiStop and GolgiPlug (BD Biosciences) in 10\% fetal bovine serum (FBS)-supplemented RPMI 1640 for $5 \mathrm{~h}$ at $37^{\circ} \mathrm{C}$. After stimulation, aliquots of cells were first stained for surface markers of T cells (CD4, CD8 $\alpha$, and CD45) and B cells (CD19 and CD45) in separate wells and then stained for intracellular IL-10 as previously described (19). A separate aliquot was first labeled with monoclonal antibodies against surface markers CD3 and CD4, followed by intracellular labeling for Foxp3 and IL-10 to determine numbers of IL-10producing Treg cells. Pulmonary cells were gated on $\mathrm{CD} 45^{+}$leukocytes for T-and B-cell panels and then analyzed for IL-10 labeling. The amount 
of baseline label of IL-10 in leukocytes $\left(\mathrm{CD} 45^{+}\right)$isolated from $I L-10^{-/-}$ mice was used as the control. Percentages of $\mathrm{CD} 4^{+} \mathrm{CD} 8^{-}, \mathrm{CD} 4^{-} \mathrm{CD} 8^{+}$, and $\mathrm{CD} 19^{+}$cells in the $\mathrm{CD} 45^{+} \mathrm{IL}-10^{+}$population were determined and used to calculate the absolute number of IL-10-producing $\mathrm{CD} 4^{+} \mathrm{T}$ cells, $\mathrm{CD}^{+}{ }^{+} \mathrm{T}$ cells, and B cells, respectively. The double-positive $\mathrm{CD} 4^{+} \mathrm{CD} 8{ }^{+}$ cells, which could also be DCs, were not included within the gates. Pulmonary leukocytes identified as IL- $10^{+} / \mathrm{CD} 8^{-} \mathrm{CD} 4^{+} \mathrm{Foxp}^{+}$were defined as pulmonary Treg cells. Aliquots of IL- $10^{+}$-labeled, PMA/ionomycin-activated pulmonary cells were stained for surface markers to identify different types of granulocytes (CD11b, Ly6G, and CD11c). FACS data were first gated on cells which were IL- $10^{+}$and then further analyzed for their expression of Ly6G, CD11b, and CD11c. Percentages of $\mathrm{Ly}_{6} \mathrm{G}^{+}$ $\mathrm{CD}_{11 b^{+}}, \mathrm{CD}_{11} \mathrm{~b}^{+} \mathrm{CD} 11 \mathrm{c}^{+}$, and $\mathrm{CD} 11 \mathrm{~b}^{+} \mathrm{CD} 11 \mathrm{c}^{-} \mathrm{Ly}_{6} \mathrm{G}^{-}$cells in the IL- $10^{+}$population were determined and used to calculate the absolute number of IL-10-producing neutrophils, dendritic cells, and macrophages, respectively.

Quantification of leukocyte cell types in Coccidioides-infected lungs. Flow cytometry was used to determine the numbers of $\mathrm{CD} 4^{+} \mathrm{T}$ cells, CD8 ${ }^{+}$T cells, B cells, natural killer cells (NK), neutrophils (PMNs), alveolar macrophages (AM), inflammatory macrophages (IM), and DCs in the lung homogenates as previously described $(19,33)$. The gating strategies were the following: $\mathrm{CD}^{+} \mathrm{CD}^{+} \mathrm{CD}^{-}, \mathrm{CD}^{+} \mathrm{CD}^{-} \mathrm{CD} 8^{+}$,

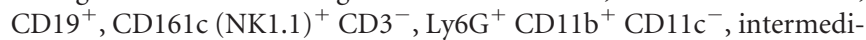

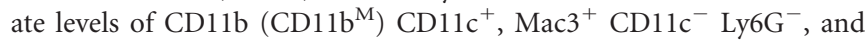
high levels of CD11b $\left(\mathrm{CD} 11 \mathrm{~b}^{\mathrm{H}}\right) \mathrm{CD} 11 \mathrm{c}^{+}$, respectively $(19,32,33)$.

Recall assays of $\mathrm{CD} 4^{+} \mathrm{T}$ cells. Splenocytes of wild-type C57BL/6 and $I L-10^{-/-}$mice immunized with the $\Delta \mathrm{T}$ vaccine were separately harvested, pooled, and macerated for isolation of $\mathrm{CD}^{+} \mathrm{T}$ cells by using a $\mathrm{CD} 4^{+}$ T-cell isolation kit (Miltenyi Biotec, Inc., Gladbach, Germany) as previously reported (35). The purity of $\mathrm{CD} 4^{+} \mathrm{T}$ cells was verified by staining the cells with fluorescein-conjugated anti-CD3 and anti-CD4 MAbs, followed by flow cytometry. The purity of $\mathrm{CD} 4^{+} \mathrm{T}$ cells was routinely above $90 \%$. The isolated $\mathrm{CD} 4^{+} \mathrm{T}$ cells were cultured in 24 -well plates $\left(2.5 \times 10^{6}\right.$ cells/well) with $2.5 \times 10^{6}$ splenocytes isolated from naive $I L-10^{-/-}$mice in $2 \mathrm{ml} \mathrm{RPMI} 1640$ containing 10\% heat-inactivated FBS, $1 \%$ streptomycin (Strep), and $1 \% \mathrm{~L}$-glutamine, to which $40 \mu \mathrm{g} / \mathrm{ml}$ of a coccidioidal antigen extract (T27K) was added. Examination of in vitro T-cell stimulation was conducted by incubation of immune splenocytes in growth medium alone or with the addition of $\mathrm{T} 27 \mathrm{~K}$ antigen (19) for $72 \mathrm{~h}$ at $37^{\circ} \mathrm{C}$ in the presence of $5 \%$ $\mathrm{CO}_{2}$. T cells incubated in growth medium alone served as negative controls. After incubation, a cocktail of protease inhibitors (Complete, EDTA-free; Roche Diagnostics, Pleasanton, CA) was added to each well, and culture supernatants were collected from the centrifuged samples $(11,950 \times g$ for 10 $\min$ at $4^{\circ} \mathrm{C}$ ). The concentrations of selected cytokines were determined by using a Bio-Plex suspension array system.

Intracellular cytokine staining. Aliquots of pulmonary leukocytes were stimulated with anti-CD3 and anti-CD28 in the presence of GolgiStop in $10 \%$ FBS-supplemented RPMI 1640 for $4 \mathrm{~h}$ at $37^{\circ} \mathrm{C}$. Permeabilized cells were stained with selected fluorochrome-conjugated monoclonal antibodies (anti-IFN- $\gamma$, anti-IL-5, or anti-IL-17A) to determine absolute numbers of the specific cytokine-producing $\mathrm{CD} 4^{+} \mathrm{T}$ cells as previously described $(19,36)$. The leukocytes were gated for $\mathrm{CD} 4^{+} \mathrm{CD} 8^{-} \mathrm{T}$ cells, and numbers of cytokine-producing cells were determined. The absolute numbers of the specific cytokine-producing $\mathrm{CD} 4^{+} \mathrm{T}$ cells relative to the total lung-infiltrating leukocytes per lung homogenate at 8 and 12 days postchallenge were calculated by multiplying the percentage of each gated population by the total number of viable pulmonary leukocytes determined by hemocytometer counts as described above.

Histopathology. Comparative histopathology was conducted with excised whole lung organs from Coccidioides-infected, nonvaccinated, and vaccinated wild-type C57BL/6 and $I L-10^{-1-}$ mice. The animals were sacrificed at 14 days postchallenge (4 mice per group) as reported elsewhere (31). Tissue fixation and embedding procedures were performed as described previously (31). Paraffin sections ( $5 \mu \mathrm{m}$ thick) were stained with hematoxylin and eosin (H\&E) or Gomori methenamine silver stain
(GMS) by standard procedures. Sections were examined using a Leica DMI6000 microscope equipped with an automated turboscan stage (Objective Imaging, Ltd., Cambridge, United Kingdom), and microscope images of infected lung tissue were acquired and analyzed using Surveyor software (Objective Imaging) as reported elsewhere (32).

Statistical analyses. The Student Newman-Keuls test, a type of analysis of variance statistical method for multisample comparisons, was used to analyze the enzyme-linked immunosorbent assay results, cytokine concentrations, absolute numbers of lung-infiltrating immune cells, and percentages of specific cytokine-producing $\mathrm{T}$ cells as previously reported (36). All pairwise comparisons of the fungal burden, measured as the CFU between nonvaccinated versus vaccinated mice and between wild-type versus $I L-10^{-1-}$ mice, were analyzed using the Mann-Whitney $U$ test as reported previously (31). Survival data were examined by the KaplanMeier test using log rank analysis to compare survival plots, as reported previously (31). A $P$ value of $<0.05$ was considered statistically significant.

\section{RESULTS}

Vaccinated C57BL/6 mice revealed early but limited production of IL-10 after Coccidioides infection. C57BL/6 mice were vaccinated with the live, attenuated vaccine strain $(\Delta \mathrm{T})$ and challenged with a potentially lethal dose of Coccidioides spores as previously described $(19,31,32)$, except that the interval between the last vaccination and challenge was extended from 4 to 16 weeks. At 8 weeks postvaccination, there was no detectable live, attenuated Coccidioides $\Delta \mathrm{T}$ cells in any of the tissue or organ homogenates examined, including cutaneous tissue at the injection site, draining lymph nodes, lungs, spleen, liver, and kidneys (the detection limit was 5 CFU per organ). We extended the interval prior to challenge to 16 weeks in order to evaluate the memory T-cell response. Cytokine assays of infected lung homogenates of mice revealed distinct differences in the kinetics of IL-10 production between the vaccinated $(\Delta \mathrm{T})$ and nonvaccinated mice during the first 14 DPC (Fig. 1A). The concentration of IL-10 was significantly elevated in vaccinated mice starting at 7 DPC, peaked at 9 DPC, and then declined between 11 and 14 DPC (Fig. 1A). In contrast, lung homogenates of nonvaccinated mice showed a steady increase in IL-10 production between 7 and 14 DPC, which correlated with the increase in fungal burden in the lungs and dissemination of the pathogen to the spleen, as previously reported (19). Since recruitment of leukocyte subpopulations in lungs of WT mice has been shown to be comparable at 12 and 14 DPC (19), we decided to conduct our immunological assays at 8 and 12 DPC, which represented the time points before and after dissemination occurred. In addition, because $I L-10$ gene expression is expected to precede an increase in IL-10 cytokine production, QRT-PCR analysis of the amounts of $I L-10$ transcript was conducted at these same time points before the peaks of IL-10 concentration were detected in the lungs of vaccinated mice ( 9 DPC) and nonvaccinated mice (14 DPC). The results were coincident with upregulation of IL-10 production in the lungs of nonvaccinated but not vaccinated mice (Fig. 1B). The amount of IL-10 transcript in the lungs of vaccinated mice showed no significant change between 8 and 12 DPC, while upregulation of IL-10 expression in lung homogenates of nonvaccinated mice revealed an approximate 35 -fold increase during this same period postchallenge. These observations support previous findings indicating that there is a direct correlation between amounts of IL-10 production and susceptibility to Coccidioides infection $(12,13)$.

Treg cells contributed to IL-10 production in the vaccinated mice. We next attempted to determine which lung-infiltrated im- 

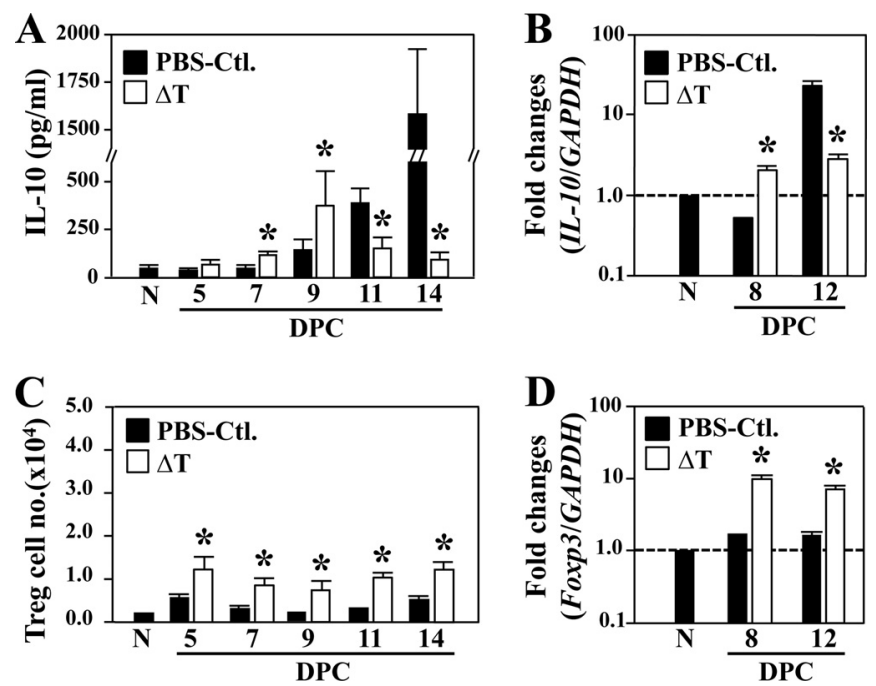

FIG 1 IL-10 production in lungs of vaccinated $(\Delta \mathrm{T})$ and nonvaccinated (PBSCtl.) C57BL/ 6 mice did not directly correlate with recruitment of CD4 ${ }^{+}$Treg cells. (A and B) IL-10 cytokine levels (A) and fold changes of transcripts (B) in lung homogenates at the indicated DPC following intranasal challenge with approximately 60 to 80 Coccidioides spores were determined for C57BL/6 mice that were challenged at 16 weeks after the final vaccination. Nonvaccinated and noninfected mice $(\mathrm{N})$ of the same age and gender were included for determination of the baseline amounts of IL-10 transcript and protein. (C and D) The absolute number of Foxp $3^{+} \mathrm{CD} 4{ }^{+} \mathrm{CD} 25^{+}$Treg cells (C) in lung homogenates of the mice was determined at the indicated time points. Total RNA was also isolated from duplicated sets of mice and used for determination of the fold changes of Foxp3 expression at 8 and 12 DPC (D). The assays were conducted in two independent experiments. Data are means \pm SEM of 4 mice per group. Asterisks indicate $P<0.05$ compared to nonvaccinated mice.

mune cells contributed to IL-10 production in the Coccidioidesinfected lungs. Since it is well established that $\mathrm{CD}^{+} \mathrm{CD}^{+}$ Foxp $3^{+}$T cells (Treg phenotype) can produce high amounts of IL-10 during microbial infection $(4,5)$, we employed cytometric techniques to determine the absolute numbers of Tregs that were recruited to the Coccidioides-infected lungs of vaccinated and nonvaccinated mice during the initial 14 days postchallenge. Our results revealed that Treg cells were sustained at a significantly elevated number in vaccinated compared to nonvaccinated mice during this period (Fig. 1C). We also compared expression of Foxp3 in lung homogenates of the two groups of infected mice (Fig. 1D). The amount of Foxp3 transcript was significantly higher in homogenates of vaccinated than in nonvaccinated mice at 8 and 12 DPC, and both showed little change during this interval. Unexpectedly, the kinetics of Treg recruitment did not correlate with the peak of IL-10 production in nonvaccinated mice, suggesting that other immune cells in lung homogenates of this group of mice contribute to the sharp increase in IL-10 concentration.

Comparison of the relative contributions of IL-10 production by immune cell subpopulations recruited to lungs of vaccinated versus nonvaccinated mice. We systematically investigated leukocyte subpopulations that were capable of producing IL-10 in Coccidioides-infected lungs. The percentages of leukocytes positive for IL-10 production in lungs of vaccinated mice were comparable to nonvaccinated mice at 8 and 12 DPC (Fig. 2A). Further analyses showed that a significantly higher percentage and number of the gated IL-10-producing lymphocytes were CD ${ }^{+} \mathrm{T}$ cells of vaccinated than in nonvaccinated mice at 8 and 12 DPC
(Fig. 2B, D and E). The total numbers of $\mathrm{CD} 4^{+} \mathrm{IL}-10^{+} \mathrm{T}$ cells were further examined for their expression of Foxp3. The numbers of IL-10-producing Foxp $3^{+} \mathrm{CD} 4^{+}$cells were significantly elevated in the lungs of vaccinated mice at 8 and 12 DPC (Fig. 2D and E). On the other hand, the lungs of nonvaccinated mice had a higher percentage and number of $\mathrm{CD}^{+}{ }^{+} \mathrm{T}$ cells producing IL-10 at 12 DPC (Fig. 2B and E). Interestingly, a significantly elevated percentage and total number of PMNs in Coccidioides-infected lungs of nonvaccinated mice were capable of producing IL-10 at both 8 and 12 DPC compared to vaccinated mice (Fig. 2C, D, and E). IL-10-producing CD $19^{+}$B cells were not detected in Coccidioidesinfected lungs during the first 2 weeks postchallenge (Fig. 2D and E). IL-10-producing granulocytes, including PMNs, DCs, and macrophages, were the major innate cell types recruited to the Coccidioides-infected lungs of both nonvaccinated and vaccinated mice. In summary, our results showed that $\mathrm{CD} 4{ }^{+} \mathrm{T}$ cells, both Foxp $^{+}$and Foxp $3^{-}$cells, and DCs and macrophages were the major activated immune cells that produced IL-10 in the lungs of vaccinated mice, while $\mathrm{CD} 8^{+} \mathrm{T}$ cells, $\mathrm{PMNs}$, and macrophages were the major cell types that contributed to the sharp increase of IL-10 in the lungs of nonvaccinated mice after 11 days postchallenge (Fig. 1A and 2D and E).

Enhanced recruitment of $\mathrm{CD}^{+} \mathrm{T}$ cells to lungs of $\mathrm{IL}-10^{-/-}$ mice during the first 8 days postchallenge. To investigate whether acquisition of leukocyte subpopulations in lungs was altered in the absence of IL-10, we compared the inventory of CD $4^{+}$ and $\mathrm{CD}^{+}{ }^{+} \mathrm{T}$ cells, B cells, NK cells, PMNs, alveolar and inflammatory macrophages, and dendritic cells that had infiltrated Coccidioides-infected lungs of WT and $I L-10^{-/-}$mice at 8 and 12 DPC. The numbers of these examined immune cells of both naive $I L-10^{-1-}$ and WT mice were comparable to vaccinated WT mice before challenge (0 DPC), as we previously reported (19). No significant difference in the numbers of these immune cells was detectable between vaccinated WT and $I L-10^{-1-}$ mice before challenge. Total numbers of CD45 ${ }^{+}$leukocytes were comparable in lungs of $I L-10^{-/-}$and wild-type mice during the first 12 DPC. Significantly elevated levels of CD ${ }^{+} \mathrm{T}$ cells and B cells accompanied by reduced percentages of pulmonary-infiltrating PMNs were observed in lung homogenates of vaccinated compared to nonvaccinated IL-10-deficient mice at 8 and 12 DPC (Fig. 3A to D). In addition, the percentage of $\mathrm{CD} 8^{+} \mathrm{T}$ cells of vaccinated IL-10 $0^{-/-}$mice was significantly higher at $12 \mathrm{DPC}$ than in the nonvaccinated mice (Fig. $3 \mathrm{~B}$ ). These results were comparable to those of the nonvaccinated and vaccinated wild-type mice (Fig. 3A to D) (19), except that a significantly higher percentage of CD $4^{+} \mathrm{T}$ cells was revealed in the lungs of nonvaccinated and vaccinated $I L$ $10^{-1-}$ mice at $8 \mathrm{DPC}$ (Fig. $3 \mathrm{~A}$ to $\mathrm{D}$ ). These results suggested that IL-10 mainly impacts the acquisition of $\mathrm{CD} 4^{+} \mathrm{T}$ cells following pulmonary infection with Coccidioides, particularly during the first 8 days postchallenge.

$\mathrm{CD}^{+} \mathrm{T}$ cells isolated from vaccinated $\mathrm{IL}-10^{-/-}$mice respond ex vivo to Coccidioides antigen by increased production of Th1-, Th2-, and Th17-type cytokines. We compared cytokine secretion by $\mathrm{CD}^{+}{ }^{+} \mathrm{T}$ cells isolated from $\Delta \mathrm{T}$-vaccinated wild-type and $I L-10^{-/-}$mice at 16 weeks after the final step of the immunization protocol. Splenocytes isolated from naive $I L-10^{-/-}$mice were used as antigen-presenting cells (APCs) to ensure that the source of IL-10 was from CD4 ${ }^{+} \mathrm{T}$ cells. The concentrations of selected cytokines, which are indicators of Th1 (Fig. 4A and B), Th2 (Fig. 4C and D), and Th17 (Fig. 4E and F) polarized re- 
A

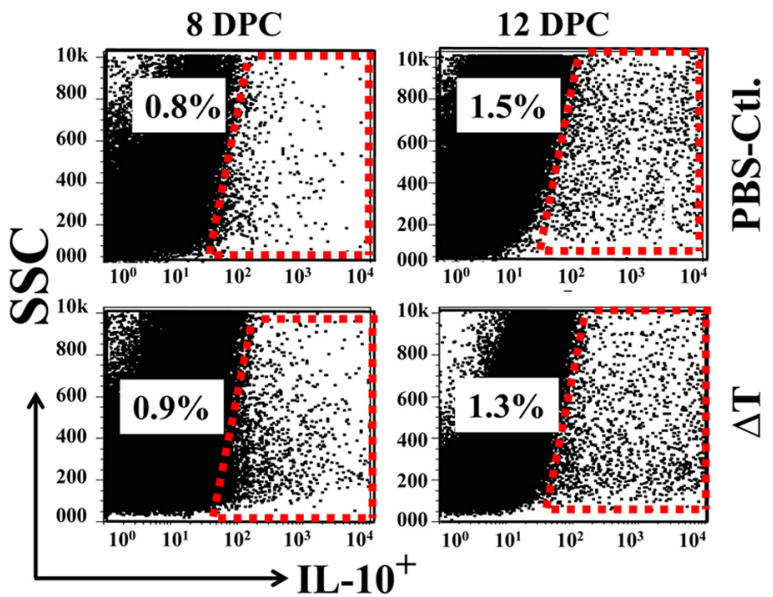

B

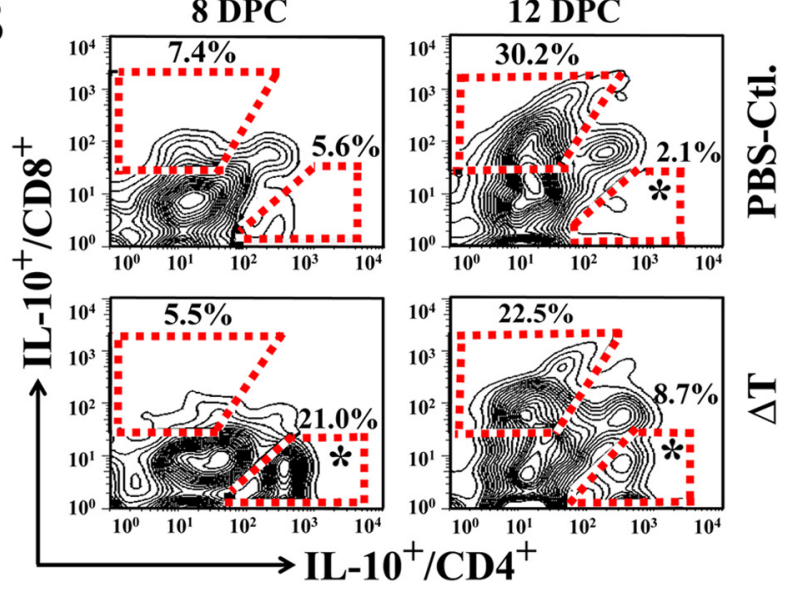

C

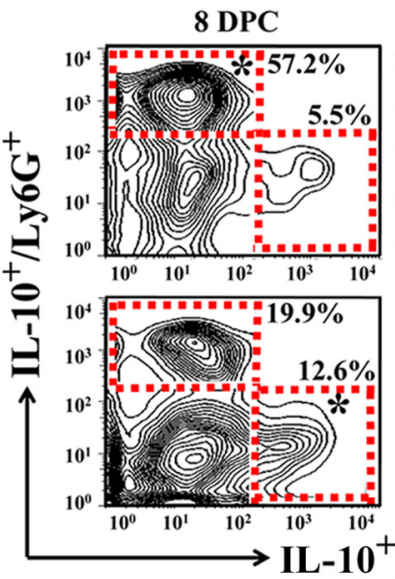

D

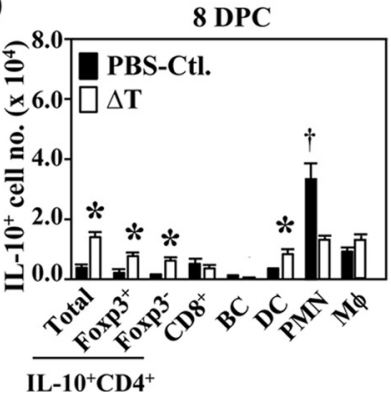

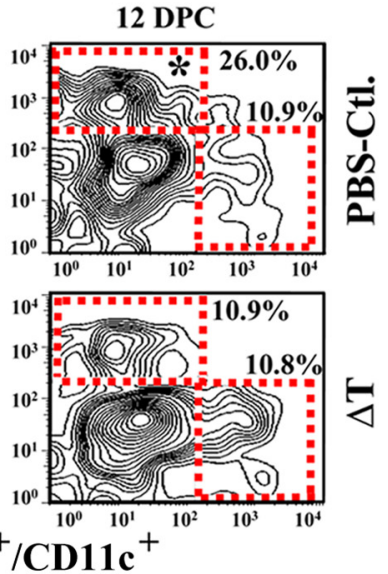

E

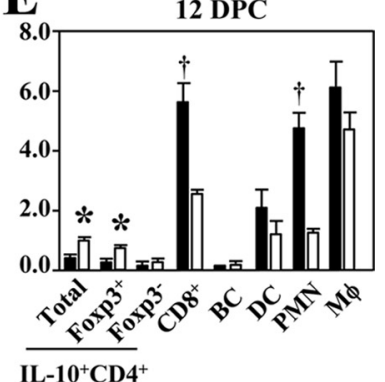

sponses, were highest in $\mathrm{T}$ cells isolated from $\Delta \mathrm{T}$-vaccinated $I L$ $10^{-1-}$ mice upon stimulation ex vivo with Coccidioides-specific T27K antigen $(P<0.01)$. CD4 ${ }^{+} \mathrm{T}$ cells isolated from nonvaccinated wild-type or IL-10 knockout mice showed minimal ex vivo production of the selected cytokines when cocultured with the T27K antigen. Likewise, isolated immune $\mathrm{CD}^{+} \mathrm{T}$ cells cultured in the absence of T27K consistently showed low levels of cytokine production. Taken together, these data suggest that vaccine-induced $\mathrm{CD} 4^{+}$memory $\mathrm{T}$ cells differentiated in both wild-type and $I L-10^{-/-}$mice at least by 16 weeks after the final vaccination step. On the other hand, the presence of IL-10 suppressed the secretion of cytokines by $\mathrm{CD} 4^{+} \mathrm{T}$ cells in a self-regulatory manner.

Vaccinated $I L-10^{-/-}$mice undergo expansion of effector memory $T$ cells during the first $8 \mathrm{DPC}$. To determine whether the elevated, ex vivo response of $\mathrm{CD} 4^{+} \mathrm{T}$ cells isolated from vaccinated $I L-10^{-/-}$mice described above translated into changes in $\mathrm{T}$ effector cell memory $\left(\mathrm{T}_{\mathrm{EM}}\right)$ function in the infected sites, we isolated pulmonary $\mathrm{CD} 4^{+} \mathrm{T}$ cells from each mouse group and compared their expression of CD44 and CD62L at 8 and 12 DPC. Both vaccinated and nonvaccinated $I L-10^{-/-}$mice consistently showed higher percentages and numbers of $\mathrm{CD} 44^{+} \mathrm{CD}_{2} \mathrm{~L}^{-} \mathrm{CD} 4^{+} \mathrm{T}$ cells $\left(\mathrm{T}_{\mathrm{EM}}\right)$ during the initial 12 days postchallenge compared to wildtype mice (Fig. 5A). Phenotypic analysis of activated, pulmonary $\mathrm{CD}^{+} \mathrm{T}$ cells revealed that significantly higher numbers of Th1 $\left(\mathrm{IFN}-\gamma^{+}\right)$and Th17 $\left(\mathrm{IL}-17 \mathrm{~A}^{+}\right)$cells were present in lungs of vaccinated and nonvaccinated $I L-10^{-/-}$mice than WT mice at 8 DPC (Fig. 5B). At 12 DPC, significant differences were observed between absolute numbers of Th1 and Th17 cells isolated from nonvaccinated $I L-10^{-1-}$ versus WT mice, while vaccinated mice of both strains had comparable numbers of Th1 and Th17 cells. No significant difference was detected in the absolute numbers of Th2 (IL-5) cells between these two groups of mice during the first 12 days postchallenge (Fig. 5B).

Nonvaccinated $I L-10^{-/-}$mice showed significantly better clearance of Coccidioides and prolonged survival compared to nonvaccinated WT mice. Relative degrees of protection against coccidioidomycosis were determined by measuring numbers of $\mathrm{CFU}$ in the lungs and spleen of wild-type and $I L-10^{-/-}$mice at 14 DPC. The mean CFU in the lungs of nonvaccinated $I L-10^{-/-}$mice $\left(5.2 \pm 1.4 \log _{10}\right)$ was significantly lower than that of wild-type mice (6.9 $\left.\pm 1.3 \log _{10} ; P=0.0002\right)$ (Fig. 6 A). Similarly, nonvaccinated $I L-10^{-1-}$ mice showed significantly reduced fungal burdens in their spleens $\left(2.6 \pm 1.7 \log _{10}\right)$ than did nonvaccinated WT mice

FIG 2 Diverse subsets of lymphocytes and granulocytes produced IL-10 in the lungs during Coccidioides infection. Pulmonary cells were isolated from the nonvaccinated (PBS-Ctl.) or vaccinated $(\Delta \mathrm{T}) \mathrm{C} 57 \mathrm{BL} / 6$ mice at 8 or $12 \mathrm{DPC}$. (A) Dot plots of gated IL-10-producing cells in the pulmonary leukocyte population $\left(\mathrm{CD} 45^{+}\right)$. (B) Percentages of $\mathrm{CD}^{+}$versus $\mathrm{CD} 8^{+}$cells in the gated $\mathrm{IL}-10^{+}$populations. Numbers juxtaposed to the gates give the mean percentage of the subset populations within the gated IL- $10^{+}$cells. (C) Percentages of $\mathrm{CD}_{11 \mathrm{c}^{+}}$versus Ly6G ${ }^{+}$subsets of granulocytes, which represented DCs and PMNs in the gated IL- $10^{+}$cell population. ( $\mathrm{D}$ and $\mathrm{E}$ ) Total numbers of IL-10producing $\mathrm{CD} 4^{+} \mathrm{T}$ cells in the lungs were further divided into Foxp $3^{+}$and Foxp $3^{-}$subpopulations. The numbers of IL-10-producing $\mathrm{CD} 8^{+} \mathrm{T}$ cells, B cells $(\mathrm{BC})$, dendritic cells, neutrophils (PMN), and macrophages $(\mathrm{M} \phi)$ per lung organ were also measured as described in Materials and Methods at 8 and 12 DPC. Asterisks indicate significantly higher numbers of IL-10-producing cell numbers in vaccinated compared to nonvaccinated mice, while daggers indicate higher numbers in the nonvaccinated mice compared to vaccinated mice $(P<0.05)$. Data are representative of 2 independent experiments with similar results. 

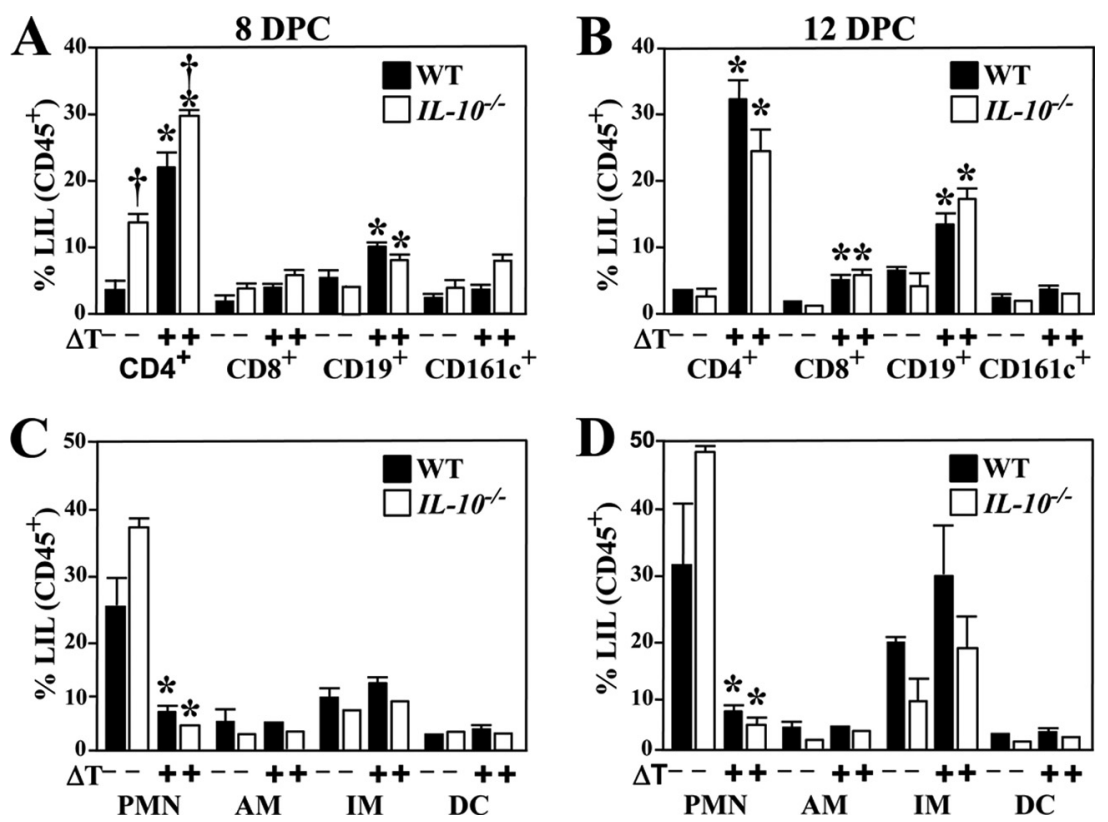

FIG 3 Enhanced acquisition of CD4 ${ }^{+}$T cells in lung homogenates of Coccidioides-infected $I L-10^{-1-}$ mice. Pulmonary cells were isolated from the nonvaccinated or vaccinated Coccidioides-infected WT and $I L-10^{-1-}$ mice that were sacrificed at $8 \mathrm{DPC}$ (A and C) or $12 \mathrm{DPC}$ (B and D). Percentages of each immune cell subset within the gated $\mathrm{CD}_{4} 5^{+}$population were determined as described in Materials and Methods. Data are presented as means \pm SEM of 4 mice per group. Asterisks indicate significant differences between the vaccinated and nonvaccinated mice of the same strain, while the dagger represents a significant difference between the $I L-10^{-1-}$ and WT mice $(P<0.05)$.

$\left(4.1 \pm 1.8 \log _{10} ; P=0.0037\right)$ (Fig. 6B). As expected, both vaccinated $I L-10^{-1-}$ and wild-type mice showed comparable reductions of fungal burden in both their lungs $\left(2.2 \pm 1.1 \log _{10}\right.$ and $2.3 \pm 0.9 \log _{10}$, respectively) and spleens $\left(1.1 \pm 0.4 \log _{10}\right.$ and $1.6 \pm$ $0.8 \log _{10}$, respectively). Additional comparative studies revealed that the nonvaccinated $I L-10^{-/-}$mice showed a significant increase in the percent survival compared to nonvaccinated wild- type mice after a lethal intranasal challenge with approximately 80 spores $(P<0.01)$ (Fig. $6 \mathrm{C})$. Both vaccinated $I L-10^{-/-}$and wildtype mice showed $100 \%$ survival after 60 days postchallenge $(P<$ 0.001) (Fig. 6C).

Comparative histopathology of nonvaccinated $I L-10^{-/-}$and wild-type mice showed differences in concentrations of parasitic cells in infected lung tissue. At 14 DPC, lungs of both non-
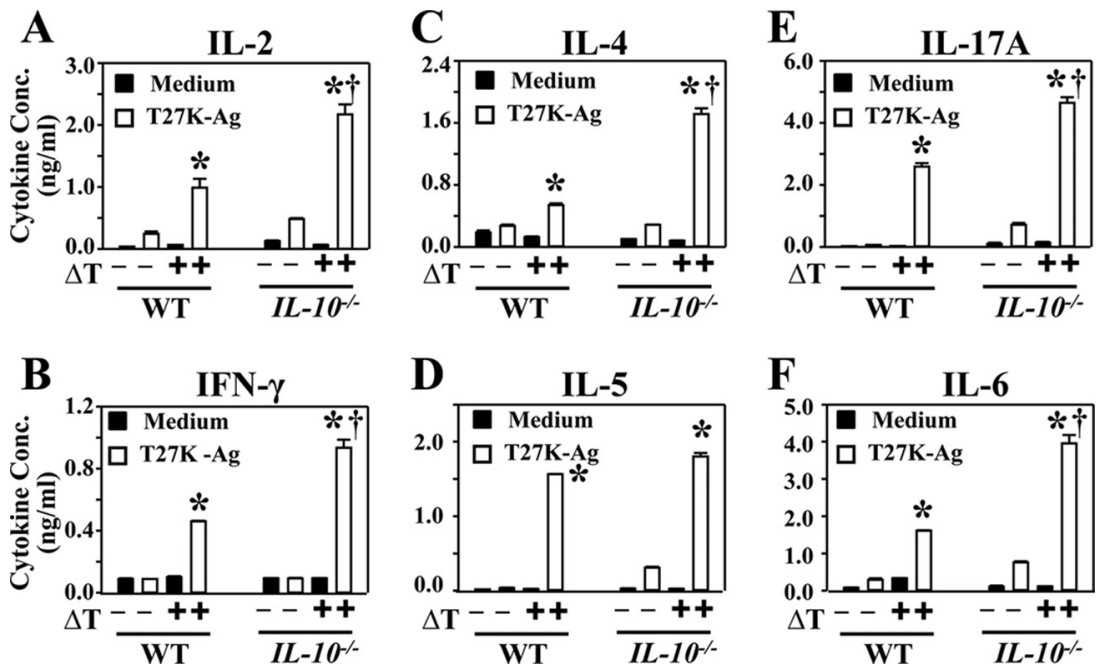

FIG 4 CD4 ${ }^{+}$T cells isolated from vaccinated $I L-10^{-/-}$mice secreted higher amounts of Th1-, Th2-, and Th17-type cytokines upon stimulation with Coccidioides antigen than did nonvaccinated mice. CD4 ${ }^{+} \mathrm{T}$ cells were isolated from splenocytes of WT and $I L-10^{-1-}$ mice immunized with the $\Delta \mathrm{T}$ vaccine or PBS at 16 weeks postvaccination. Isolated $\mathrm{CD} 4^{+} \mathrm{T}$ cells were cultured in the presence or absence of Coccidioides $\mathrm{T} 27 \mathrm{~K}$ antigen. Concentrations of representative Th1 cytokines (IL-2 and IFN- $\gamma$ ) (A and B), Th2 cytokines (IL-4 and IL-5) (C and D), and Th17 cytokines (IL-6 and IL-17A) (E and F) in supernatants of antigen-stimulated immune cells were compared. Statistically significant differences in cytokine production between the $\Delta \mathrm{T}$-vaccinated and nonvaccinated mice of the same strain are indicated by asterisks $(P<0.05)$. Daggers indicate a significant difference between WT and $I L-10^{-1-}$ mice $(P<0.01)$. The results are representative of 2 separate experiments with 4 mice per group. 

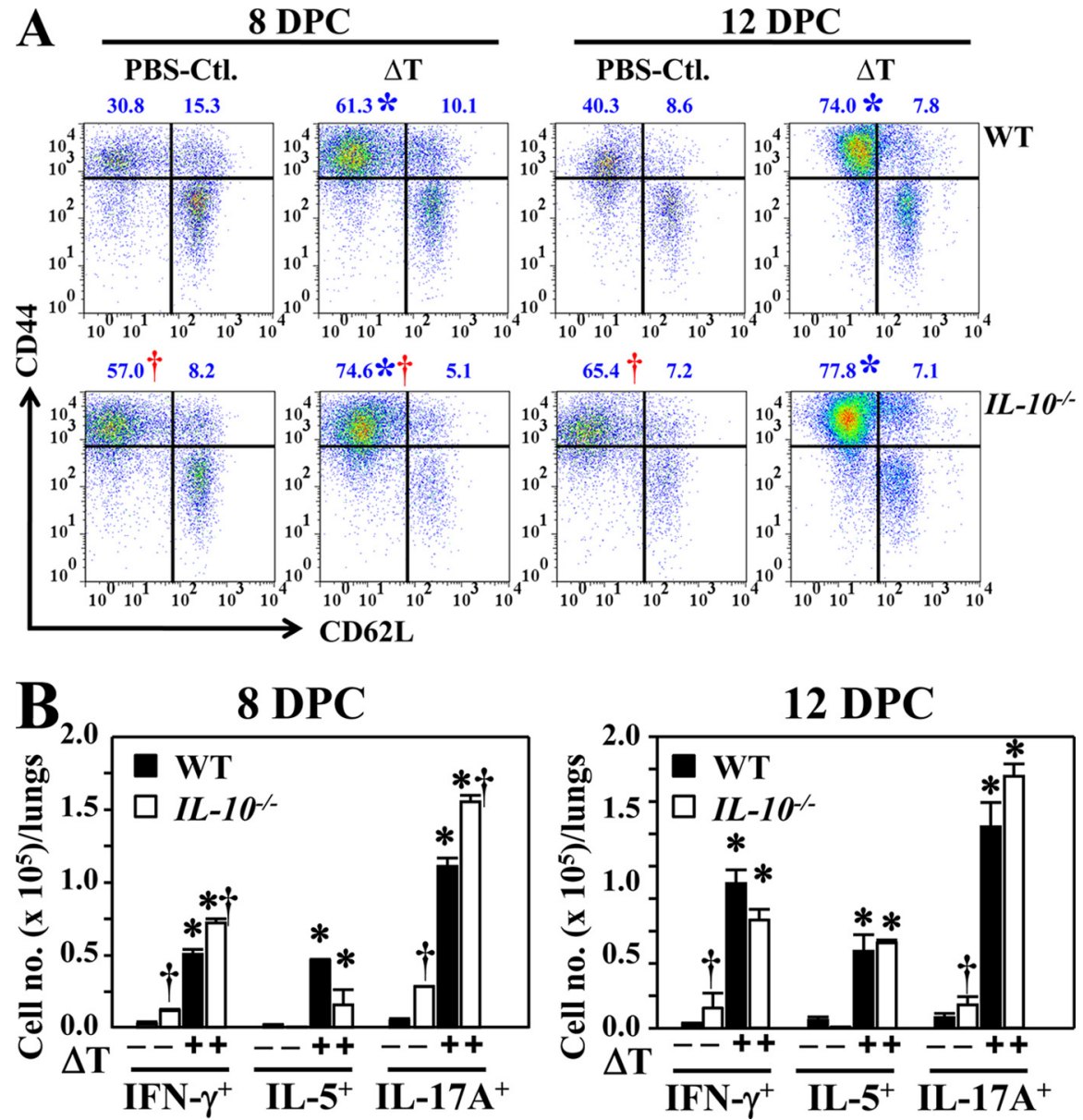

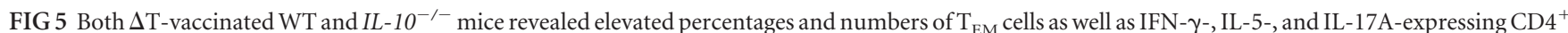
$\mathrm{T}$ cells compared to nonvaccinated mice. (A) Percentages of $\mathrm{T}_{\mathrm{EM}}\left(\mathrm{CD} 4^{+} \mathrm{CD} 44^{+} \mathrm{CD}_{2}{ }^{-}\right)$and $\mathrm{T}_{\mathrm{CM}}\left(\mathrm{CD} 4^{+} \mathrm{CD} 44^{+} \mathrm{CD}_{2} \mathrm{~L}^{+}\right)$cells within the gated $\mathrm{CD} 44^{+} \mathrm{T}$-cell population in the lungs of nonvaccinated (PBS-Ctl.) versus vaccinated $(\Delta \mathrm{T})$ mice are shown at 8 or $12 \mathrm{DPC}$. Numbers above the gates indicate the mean percentages of the gated $\mathrm{T}_{\mathrm{EM}}$ and $\mathrm{T}_{\mathrm{CM}}$ subsets. (B) The cell numbers of gated, specific cytokine-producing CD4 ${ }^{+} \mathrm{T}$ cells per lung were determined by intracellular cytokine staining. Asterisks indicate significantly higher cell numbers of responsive T-cell subpopulations in lungs of vaccinated compared to nonvaccinated mice, while the daggers indicate higher numbers of selected cytokine-producing cells in $I L-10^{-/-}$mice compared to WT counterparts. Error bars indicate standard errors. The results reported are representative of two independent experiments.

vaccinated WT and $I L-10^{-/-}$mice had coalescing abscesses that constituted over $50 \%$ of the organs. While $50 \%$ of the vaccinated WT mice had 1 to 2 small granulomas ( $\sim 1$ to $2 \mathrm{~mm}$ in diameter), the others revealed no gross evidence of abscess in their lungs. No vaccinated $I L-10^{-/-}$mice had visible lesions. Cross-sections of visible abscesses in lungs of both nonvaccinated WT and $I L-10^{-/-}$ mice were examined ( 4 mice per strain). Since most of the vaccinated mice did not show any visible lesions in their lungs, we randomly examined tissue sections obtained from anterior, middle, and posterior regions (6 sections per mouse). Our results revealed that both nonvaccinated WT and $I L-10^{-/-}$mice had intense suppurative inflammation associated with Coccidioides infection (Fig. 7A to D), although there were significant differences between the CFU in the lungs of these two strains of mice (see Fig. $6 \mathrm{~A})$. Sectioned lungs of wild-type mice revealed large numbers of spherules in various stages of development. When viewed at higher magnification (Fig. 7B), densely stained regions corresponding to concentrated inflammatory cells were visible, juxtaposed to mature spherules. Most of the spherules had ruptured and released their endospores. Inflammatory cells appeared to
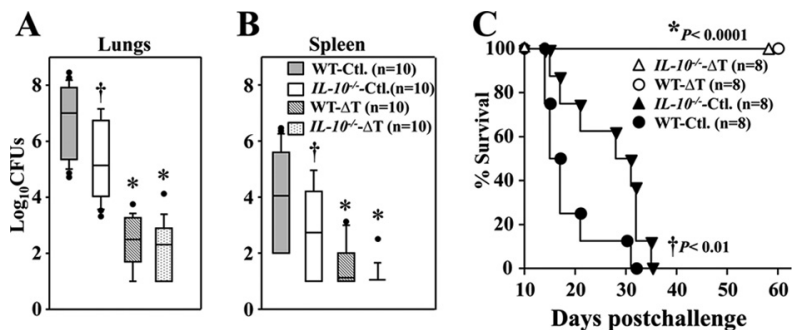

FIG 6 Both vaccinated WT and $I L-10^{-1-}$ mice significantly reduced the fungal burden in their lungs and spleen and showed prolonged survival compared to nonvaccinated mice. The numbers of $\mathrm{CFU}$ of $C$. posadasii detected in dilution plate cultures of lung (A) and spleen (B) homogenates of WT and IL$10^{-1-}$ mice that had been vaccinated with the $\Delta \mathrm{T}$ vaccine $(\Delta \mathrm{T})$ or immunized with PBS (Ctl.) as controls are reported at 14 DPC. All mice were challenged by the intranasal route with 80 viable spores isolated from the virulent strain. The horizontal lines indicate the mean CFU determinations. (C) Survival plots are presented for WT and $I L-10^{-1-}$ mice vaccinated with the $\Delta \mathrm{T}$ vaccine or treated with PBS as controls. Asterisks indicate a statistically significant difference $(P<0.05)$ between CFU in the lungs and spleen of the vaccinated versus nonvaccinated mice of the same strain, while the daggers indicate significantly reduced CFU in the $I L-10^{-/-}$mice versus the wild-type counterpart. The results are representative of 2 separate experiments. 


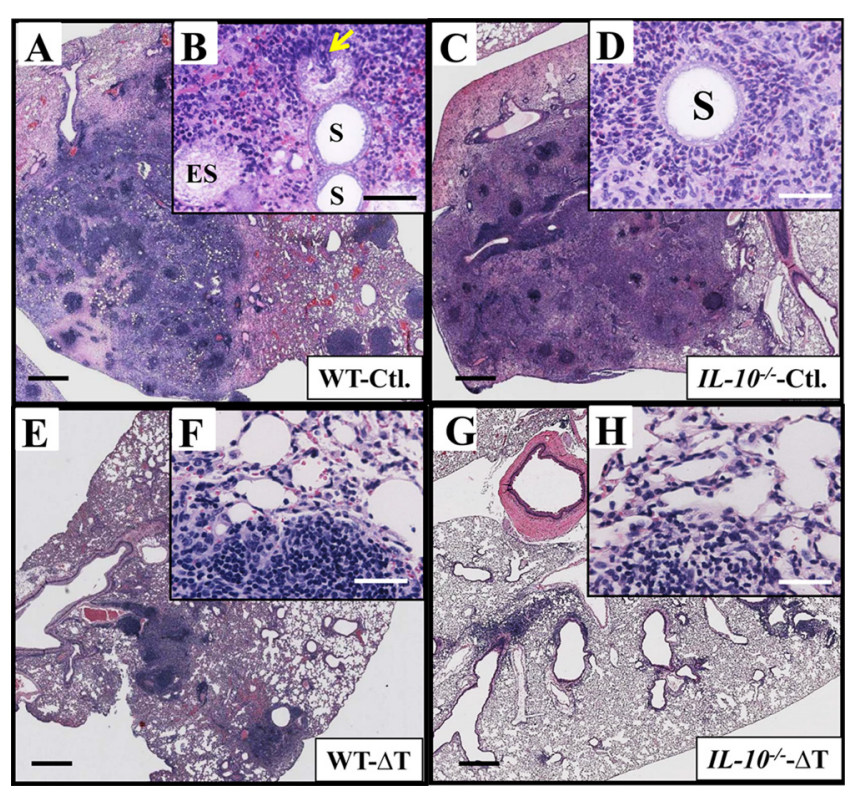

FIG 7 Comparative histopathology of Coccidioides-infected lungs revealed greater consolidation of inflammatory tissue in both vaccinated WT and $I L$ $10^{-/-}$mice compared to nonvaccinated mice. Tissue sections were prepared from lungs of the nonvaccinated (A to $\mathrm{D}$ ) and vaccinated (E to $\mathrm{H}$ ) mice at 14 DPC. The large abscesses of the nonvaccinated WT and $I L-10^{-/-}$mice contained concentrated inflammatory cells without apparent organization (A and C). Representative images revealed higher numbers of Coccidioides spherules surrounded by areas of necrosis in the nonvaccinated WT mice (B) compared to the $I L-10^{-/-}$mice (D). Inflammatory cells converged to the sites of spherule rupture and in some cases were visible within the spherule matrix of the nonvaccinated mice (arrows in panel B). High numbers of inflammatory cells also surrounded spherules $(\mathrm{S})$ prior to endosporulation in $I L-10^{-1-}$ mice. In contrast, both vaccinated wild-type and $I L-10^{-1-}$ mice showed localized recruitment of inflammatory cells surrounded by normal tissue $(\mathrm{E}$ to $\mathrm{H})$ representive of a protective response, compared to nonvaccinated mice. Bars, $500 \mu \mathrm{m}$ (A, $\mathrm{C}, \mathrm{E}$, and $\mathrm{G})$ or $100 \mu \mathrm{m}(\mathrm{B}, \mathrm{D}, \mathrm{E}, \mathrm{F}$, and $\mathrm{H})$.

have converged to the sites of spherule rupture and in some cases were visible within the spherule matrix (Fig. 7B, arrow). The histopathology of sectioned lungs of nonvaccinated $I L-10^{-1-}$ mice revealed significantly fewer spherules. Unlike the wild-type mice, mature spherules that had released their endospores were rarely observed, although dense clusters of infiltrated inflammatory cells were visible, often juxtaposed to young spherules in stages of development prior to endosporulation (Fig. 7D, labeled with an S). The histopathology of lungs obtained from both vaccinated wildtype and $I L-10^{-I-}$ mice clearly showed more condensed inflammation and consolidation of the infection than did infected lungs of either nonvaccinated WT or $I L-10^{-1-}$ mice (Fig. $7 \mathrm{E}$ to $\mathrm{H}$ ). Rarely were parasitic cells observed within an inflammation region in the lungs of the two groups of vaccinated mice (Fig. 7F and $\mathrm{H}$ ), and the host tissue adjacent to the abscesses revealed structural features of normal lung tissue.

\section{DISCUSSION}

IL-10 has a major impact on the regulation of inflammation during the course of a wide range of infectious diseases (reviewed in references 3 and 5). Extensive evidence supports the notion that persistently elevated IL-10 production during onset of coccidioidomycosis contributes to pathogen proliferation, dissemination, and disease severity $(11-14)$. Fierer and coworkers $(13,14)$ re- ported that nonvaccinated, Coccidioides-challenged C57BL/6 mice produce higher amounts of IL-10 than resistant DBA2 mice during the early stage of pulmonary infection (10 to 16 days postchallenge) when the pathogen is tissue invasive and disseminates from the lungs to other body organs. To explore the effects of IL-10 on development of vaccine immunity to Coccidioides infection, we analyzed the kinetics of IL-10 secretion in the lungs of $\mathrm{C} 57 \mathrm{BL} / 6$ mice that had been vaccinated with a protective live, attenuated $\Delta \mathrm{T}$ vaccine (31). Our results show that in nonvaccinated and vaccinated mice during the onset of pulmonary infection with Coccidioides, distinct patterns of IL-10 secretion exist, perhaps involving different sources of the cytokine, and result in unique regulatory pathways. Due to temporal and spatial differences in cell-specific IL-10 expression, it is conceivable that the cytokine has different effects, depending on its source (37). Published studies on the role of IL-10 in coccidioidomycosis have focused on its role in disease progression and impact on innate immunity of nonvaccinated mice. This study is the first to analyze the cellular sources of IL-10 in Coccidioides-infected lungs of nonvaccinated and vaccinated C57BL/6 mice and the effects of loss of IL-10 production on vaccine immunity to infection.

We employed ex vivo assays and intracellular staining of IL-10 using pulmonary immune cells isolated from the Coccidioideschallenged C57BL/6 mice to measure sizes of each subpopulation of immune, cytokine-secreting lymphocytes and granulocytes. Although this approach has limitations of detection of IL-10 production in situ, we observed that recruitment of IL-10-producing $\mathrm{CD}^{+} \mathrm{T}$ cells, dendritic cells, neutrophils, and macrophages in lungs of nonvaccinated mice were elevated from 8 to 12 DPC, which coincided with the sharp increase of IL-10 concentration during this period. Since recruitment of these leukocyte subpopulations in lungs of nonvaccinated mice was sustained at constant numbers during 12 to 14 DPC, as previously reported (19), it is possible that the same cell types contributed to the sharp increase of IL-10 at 14 DPC (Fig. 1A). In vaccinated and infected mice, $\mathrm{CD} 4{ }^{+} \mathrm{T}$ cells, DCs, and macrophages are the main producers of IL-10. We observed that Treg cells were not elevated in the nonvaccinated mice compared to vaccinated mice. This finding is in accordance with a previous confocal microscopy study that found that an elevated IL-10 concentration was colocalized with T cells and B cells in granulomata of Coccidioides-infected human lung tissue, but not with $\mathrm{CD} 4^{+} \mathrm{CD} 25^{+}$Treg cells (38). IL-10-producing $\mathrm{CD} 4^{+}, \mathrm{CD} 8^{+} \mathrm{T}$ cells, and $\mathrm{B}$ cells have been reported to regulate immune responses during microbial infection (39-42). However, no IL-10-producing B cells were detected in the lungs of either nonvaccinated or vaccinated mice during the course of Coccidioides infection. It has been reported that T-cell-derived, but not B-cell-derived, IL-10 contributes to the suppression of the antigen-specific $\mathrm{CD}^{+}{ }^{+} \mathrm{T}$-cell response to helminth parasite infection (29). Similarly, IL-10 produced by T cells but not macrophages or PMNs influences the outcome of Leishmania infection (43). To further explore the role of IL-10-producing subsets of immune cells during Coccidioides infection, we plan to utilize IL-10 reporter mice that are conditionally deficient in IL-10 production in T cells or CD11b granulocytes $(30,42,44,45)$. These investigations are in progress, and our results will be presented in a separate report.

We observed that lung-infiltrated neutrophils, but not dendritic cells, represented a major elevated myeloid cell type among IL-10-producing pulmonary cells of nonvaccinated mice com- 
pared to vaccinated mice. Although Coccidioides-infected murine macrophages are capable of producing IL-10 in vitro (46), their roles in vivo remain to be explored. Neutrophils are one of the first lines of defense against microbial pathogens and are rapidly recruited to Coccidioides-infected lungs. Similar results have been reported for systemic infection with Yersinia enterocolitica, in which neutrophils are the major source of IL-10 (30). Coactivation of MyD88- and C-type lectin receptor-mediated signal pathways is essential for triggering neutrophils to produce IL-10 during bacterial infections (47). Host recognition of Coccidioides is dependent on Toll-like receptor 2 and Dectin-1, a C-type lectin receptor (48). Our preliminary data have shown that both MyD88 and caspase adaptor recruitment domain family member 9 (Card9), an intracellular signal adaptor for C-type lectin receptors, are essential for vaccine immunity to Coccidioides infection (unpublished data). Both MyD88- and C-type lectin-mediated pathways appear to be activated during Coccidioides infection. Taken together, our data suggest that IL-10-producing $\mathrm{CD} 4^{+} \mathrm{T}$ cells play a regulatory role in the development of protective immunity to Coccidioides infection in vaccinated mice, while IL-10producing $\mathrm{CD}^{+} \mathrm{T}$ cells and neutrophils are associated with impairment of resistance to pulmonary coccidioidomycosis in nonvaccinated mice.

Jimenez and coworkers (13) reported that the IL-10 increased susceptibility to pulmonary coccidioidomycosis in mice is partly due to downregulation of inducible nitric oxide synthase 2 (iNOS2) expression. Although iNOS2 $2^{-1-}$ mice have significantly elevated lung-infiltrating PMNs, macrophages, and dendritic cells at 11 DPC compared to wild-type mice, iNOS2 $2^{-1-}$ and wild-type mice have comparable fungal burdens (33). It appears that iNOS2 activity has limited influence on the control of Coccidioides infection in susceptible mice (33). In our study, we observed that IL-10 mainly impacted acquisition of $\mathrm{CD}^{+}{ }^{+} \mathrm{T}$ cells to sites of Coccidioides infection. Th17 cells have been shown to be the major responding immune cell type during the course of coccidioidomycosis and are essential for protection against Coccidioides infection and other dimorphic fungal pathogens $(19,20,32,36)$. Both $\mathrm{CD}^{+}$Treg and Th17 cells are derived from a common progenitor cell, but they have reciprocal maturation pathways and exert mostly opposing functions (49). We observed that both Treg IL10 -producing $\mathrm{CD}^{+} \mathrm{T}$ cells and Th17 cells were elevated in vaccinated mice upon Coccidioides infection, possibly as a consequence of maintenance of balanced immune responses through a selfregulatory mechanism of CD $4^{+} \mathrm{T}$ cells (4). Both $\mathrm{CD} 4^{+}$and $\mathrm{CD} 8^{+}$ $\mathrm{T}$ cells can mediate vaccine immunity and resistance to Coccidioides infection (50). Furthermore, $\mathrm{CD}^{+} \mathrm{T}$ cells, especially IL-17producing Th17 cells, can be primed and activated in the absence of CD4 $4^{+} \mathrm{T}$ cells and confer resistance to Blastomyces infection (51). The possibility that IL-10 production impedes acquisition of $\mathrm{CD}^{+} \mathrm{T}$ cells in lungs of Coccidioides-infected mice cannot be excluded.

Although preventing IL-10 production and/or blocking the binding of IL-10 to IL-10 receptors as vaccination strategies may favor the establishment of immune protection, we need to consider the possibility that IL-10 is required for development of long-term memory T-cell immunity (23). IL-10 has been shown to be essential for the normal recruitment of Aspergillus-specific $\mathrm{CD}^{+} \mathrm{T}$ cells to the airways of infected mice, although the mechanism is not yet known (52). In addition, loss of IL-10 can lead to a detrimental immune response accompanied by both excessive production of inflammatory cytokines and recruitment of immune cells (26). Memory T cells, which express the activation marker CD44, can be subdivided into two subpopulations: $\mathrm{T}_{\mathrm{EM}}$ and $\mathrm{T}$ central memory $\left(\mathrm{T}_{\mathrm{CM}}\right)$ cells, which are distinguished by their surface expression of the lymph node-homing receptor L-selectin $(\mathrm{CD} 62 \mathrm{~L}) . \mathrm{T}_{\mathrm{CM}}$ cells have high surface expression of CD62L and reside in the lymphoid tissue, where they replicate and expand, comprising $\mathrm{T}_{\mathrm{EM}}$ cells. The latter can subsequently be recruited to the infection sites to combat microbial infection (53). $\mathrm{T}_{\mathrm{EM}}$ cells are the major memory cell type, whereas the size of the $\mathrm{CD} 4{ }^{+} \mathrm{T}_{\mathrm{CM}}$ population is transient in Coccidioides-infected lungs. As expected, the numbers of $\mathrm{T}_{\mathrm{EM}}$, Th1, and Th17 cells were higher in lungs of the nonvaccinated $I L-10^{-1-}$ mice than in nonvaccinated wild-type mice during the first 12 DPC, which is consistent with reduced fungal burden and prolonged survival after Coccidioides infection. Both vaccinated $I L-10^{-I-}$ and wild-type mice after infection activate comparable numbers of these three protective cell types and reveal similarly reduced fungal burdens and $100 \%$ survival. Durable elevated numbers of antifungal memory $\mathrm{CD}^{+}{ }^{+} \mathrm{T}$ cells were revealed in both vaccinated and Coccidioidesinfected $I L-10^{-/-}$and wild-type mice for at least 16 weeks after vaccination. It is possible that activated $\mathrm{T}_{\mathrm{EM}}$ cells, including $\mathrm{Th} 1$ and Th17 cells, can enhance recruitment of phagocytes to alveoli and promote early reduction of fungal burden while dampening inflammatory pathology at infection sites. Hence, our data show that loss of IL-10 production does not impact the acquisition of T effector memory cells nor exacerbate immunopathology in the lungs of vaccinated mice after pulmonary Coccidioides infection. IL-10 depletion has a beneficial influence on protection during the course of coccidioidomycosis in nonvaccinated mice and no alarming effect on vaccine immunity against Coccidioides infection.

\section{ACKNOWLEDGMENT}

This work was supported by a research grant from the National Institutes of Health, NIAID (R01 AI-071118), awarded to G.T.C.

\section{REFERENCES}

1. Galgiani JN, Ampel NM, Blair JE, Catanzaro A, Johnson RH, Stevens DA, Williams PL. 2005. Coccidioidomycosis. Clin. Infect. Dis. 41:12171223. http://dx.doi.org/10.1086/496991.

2. Anonymous. 2013. Increase in reported coccidioidomycosis-United States, 1998-2011. MMWR Morb. Mortal. Wkly. Rep. 62:217-221. http: //www.cdc.gov/mmwr/preview/mmwrhtml/mm6212a1.htm.

3. Saraiva M, O'Garra A. 2010. The regulation of IL-10 production by immune cells. Nat. Rev. Immunol. 10:170-181. http://dx.doi.org/10.1038 /nri2711.

4. Jankovic D, Kugler DG, Sher A. 2010. IL-10 production by CD4 ${ }^{+}$effector T cells: a mechanism for self-regulation. Mucosal Immunol. 3:239246. http://dx.doi.org/10.1038/mi.2010.8.

5. Couper KN, Blount DG, Riley EM. 2008. IL-10: the master regulator of immunity to infection. J. Immunol. 180:5771-5777. http://www .jimmunol.org/content/180/9/5771.long.

6. Tavares D, Ferreira P, Arala-Chaves M. 2000. Increased resistance to systemic candidiasis in athymic or interleukin-10-depleted mice. J. Infect. Dis. 182:266-273. http://dx.doi.org/10.1086/315674.

7. Hernandez Y, Arora S, Erb-Downward JR, McDonald RA, Toews GB, Huffnagle GB. 2005. Distinct roles for IL-4 and IL-10 in regulating T2 immunity during allergic bronchopulmonary mycosis. J. Immunol. 174: 1027-1036. http://www.jimmunol.org/content/174/2/1027.long.

8. Deepe GS, Jr, Gibbons RS. 2003. Protective and memory immunity to Histoplasma capsulatum in the absence of IL-10. J. Immunol. 171:53535362. http://www.jimmunol.org/content/171/10/5353.long.

9. Qureshi MH, Harmsen AG, Garvy BA. 2003. IL-10 modulates host responses and lung damage induced by Pneumocystis carinii infection. J. 
Immunol. 170:1002-1009. http://www.jimmunol.org/content/170/2/100 2.long.

10. Clemons KV, Grunig G, Sobel RA, Mirels LF, Rennick DM, Stevens DA. 2000. Role of IL-10 in invasive aspergillosis: increased resistance of IL-10 gene knockout mice to lethal systemic aspergillosis. Clin. Exp. Immunol. 122:186-191. http://dx.doi.org/10.1046/j.1365-2249.2000.01382.x.

11. Fierer J. 2006. IL-10 and susceptibility to Coccidioides immitis infection. Trends Microbiol. 14:426-427. http://dx.doi.org/10.1016/j.tim.2006.07 .009 .

12. Fierer J. 2007. The role of IL-10 in genetic susceptibility to coccidioidomycosis on mice. Ann. N. Y. Acad. Sci. 1111:236-244. http://dx.doi.org /10.1196/annals.1406.048.

13. Jimenez MdP, Walls L, Fierer J. 2006. High levels of interleukin-10 impair resistance to pulmonary coccidioidomycosis in mice in part through control of nitric oxide synthase 2 expression. Infect. Immun. 74:3387-3395. http://dx.doi.org/10.1128/IAI.01985-05.

14. Fierer J, Walls L, Eckmann L, Yamamoto T, Kirkland TN. 1998. Importance of interleukin-10 in genetic susceptibility of mice to Coccidioides immitis. Infect. Immun. 66:4397-4402.

15. Brooks DG, Walsh KB, Elsaesser H, Oldstone MB. 2010. IL-10 directly suppresses CD4 but not CD8 T cell effector and memory responses following acute viral infection. Proc. Natl. Acad. Sci. U. S. A. 107:3018-3023. http://dx.doi.org/10.1073/pnas.0914500107.

16. Groux H, Bigler M, de Vries JE, Roncarolo MG. 1996. Interleukin-10 induces a long-term antigen-specific anergic state in human $\mathrm{CD} 4{ }^{+} \mathrm{T}$ cells. J. Exp. Med. 184:19-29.

17. Del Sero G, Mencacci A, Cenci E, d'Ostiani CF, Montagnoli C, Bacci A, Mosci P, Kopf M, Romani L. 1999. Anti-fungal type 1 responses are upregulated in IL-10-deficient mice. Microbes Infect. 1:1169-1180. http: //dx.doi.org/10.1016/S1286-4579(99)00245-2.

18. Gu Y, Yang J, Ouyang X, Liu W, Li H, Bromberg J, Chen SH, Mayer L, Unkeless JC, Xiong H. 2008. Interleukin 10 suppresses Th17 cytokines secreted by macrophages and T cells. Eur. J. Immunol. 38:1807-1813. http://dx.doi.org/10.1002/eji.2008838331.

19. Hung CY, Gonzalez A, Wuthrich M, Klein BS, Cole GT. 2011. Vaccine immunity to coccidioidomycosis occurs by early activation of three signal pathways of T helper cell response (Th1, Th2, and Th17). Infect. Immun. 79:4511-4522. http://dx.doi.org/10.1128/IAI.05726-11.

20. Wüthrich M, Gern B, Hung C-Y, Ersland K, Rocco N, Pick-Jacobs J, Galles K, Filutowicz H, Warner T, Evans M, Cole GT, Klein B. 2011. Vaccine-induced protection against 3 systemic mycoses endemic to North America requires Th17 cells in mice. J. Clin. Invest. 121:554-568. http: //dx.doi.org/10.1172/JCI43984

21. Döcke W-D, Asadullah K, Belbe G, Ebeling M, Höflich C, Friedrich M, Sterry W, Volk H-D. 2009. Comprehensive biomarker monitoring in cytokine therapy: heterogeneous, time-dependent, and persisting immune effects of interleukin-10 application in psoriasis. J. Leukoc. Biol. 85:582-593. http://dx.doi.org/10.1189/jlb.0408249.

22. Kalli F, Machiorlatti R, Battaglia F, Parodi A, Conteduca G, Ferrera F, Proietti M, Tardito S, Sanguineti M, Millo E, Fenoglio D, De Palma R, Inghirami G, Filaci G. 2013. Comparative analysis of cancer vaccine settings for the selection of an effective protocol in mice. J. Transl. Med. 11:120. http://dx.doi.org/10.1186/1479-5876-11-120.

23. Montagnoli C, Bacci A, Bozza S, Gaziano R, Mosci P, Sharpe AH, Romani L. 2002. B7/CD28-dependent $\mathrm{CD} 4^{+} \mathrm{CD} 25^{+}$regulatory T cells are essential components of the memory-protective immunity to Candida albicans. J. Immunol. 169:6298-6308. http://www.jimmunol.org/content /169/11/6298.long.

24. Foulds KE, Rotte MJ, Seder RA. 2006. IL-10 is required for optimal CD8 $\mathrm{T}$ cell memory following Listeria monocytogenes infection. J. Immunol. 177:2565-2574. http://www.jimmunol.org/content/177/4/2565.long.

25. Cui W, Liu Y, Weinstein JS, Craft J, Kaech SM. 2011. An interleukin21-interleukin-10-STAT3 pathway is critical for functional maturation of memory CD8 ${ }^{+} \mathrm{T}$ cells. Immunity 35:792-805. http://dx.doi.org/10.1016 /j.immuni.2011.09.017.

26. Gazzinelli RT, Wysocka M, Hieny S, Scharton-Kersten T, Cheever A, Kuhn R, Muller W, Trinchieri G, Sher A. 1996. In the absence of endogenous IL-10, mice acutely infected with Toxoplasma gondii succumb to a lethal immune response dependent on $\mathrm{CD} 4^{+} \mathrm{T}$ cells and accompanied by overproduction of IL-12, IFN- $\gamma$ and TNF- $\alpha$. J. Immunol. 157:798805 .

27. Zhou G, Ma Y, Jia P, Guan Q, Uzonna JE, Peng Z. 2010. Enhancement of IL-10 bioactivity using an IL-10 peptide-based vaccine exacerbates
Leishmania major infection and improves airway inflammation in mice. Vaccine 28:1838-1846. http://dx.doi.org/10.1016/j.vaccine.2009.11.081.

28. Xavier MN, Winter MG, Spees AM, Nguyen K, Atluri VL, Silva TMA, Bäumler AJ, Müller W, Santos RL, Tsolis RM. 2013. CD4 ${ }^{+}$T cellderived IL-10 promotes Brucella abortus persistence via modulation of macrophage function. PLoS Pathog. 9(6):e1003454. http://dx.doi.org/10 .1371/journal.ppat.1003454.

29. Haben I, Hartmann W, Specht S, Hoerauf A, Roers A, Muller W, Breloer M. 2013. T-cell-derived, but not B-cell-derived, IL-10 suppresses antigen-specific T-cell responses in Litomosoides sigmodontis-infected mice. Eur. J. Immunol. 43:1799-1805. http://dx.doi.org/10.1002/eji 201242929

30. Bouabe H, Liu Y, Moser M, Bösl MR, Heesemann J. 2011. Novel highly sensitive IL-10- $\beta$-lactamase reporter mouse reveals cells of the innate Immune system as a substantial source of IL-10 in vivo. J. Immunol. 187: 3165-3176. http://dx.doi.org/10.4049/jimmunol.1101477.

31. Xue J, Chen X, Selby D, Hung CY, Yu JJ, Cole GT. 2009. A genetically engineered live attenuated vaccine of Coccidioides posadasii protects $\mathrm{BALB} / \mathrm{c}$ mice against coccidioidomycosis. Infect. Immun. 77:3196-3208. http://dx.doi.org/10.1128/IAI.00459-09.

32. Hung CY, Hurtgen BJ, Bellecourt M, Sanderson SD, Morgan EL, Cole GT. 2012. An agonist of human complement fragment C5a enhances vaccine immunity against Coccidioides infection. Vaccine 30:4681-4690. http://dx.doi.org/10.1016/j.vaccine.2012.04.084.

33. Gonzalez A, Hung C-Y, Cole GT. 2011. Nitric oxide synthase activity has limited influence on the control of Coccidioides infection in mice. Microb. Pathog. 51:161-168. http://dx.doi.org/10.1016/j.micpath.2011.03.013.

34. Feuerer M, Hill JA, Mathis D, Benoist C. 2009 . Foxp $3^{+}$regulatory T cells: differentiation, specification, subphenotypes. Nat. Immunol. 10: 689-695. http://dx.doi.org/10.1038/ni.1760.

35. Herr RA, Hung CY, Cole GT. 2007. Evaluation of two homologous proline-rich proteins of Coccidioides posadasii as candidate vaccines against coccidioidomycosis. Infect. Immun. 75:5777-5787. http://dx.doi .org/10.1128/IAI.00807-07.

36. Hurtgen BJ, Hung CY, Ostroff GR, Levitz SM, Cole GT. 2012. Construction and evaluation of a novel recombinant $T$ cell epitope-based vaccine against coccidioidomycosis. Infect. Immun. 80:3960-3974. http://dx .doi.org/10.1128/IAI.00566-12.

37. Hedrich C, Bream J. 2010. Cell type-specific regulation of IL-10 expression in inflammation and disease. Immunol. Res. 47:185-206. http://dx .doi.org/10.1007/s12026-009-8150-5.

38. Li L, Dial SM, Schmelz M, Rennels MA, Ampel NM. 2005. Cellular immune suppressor activity resides in lymphocyte cell clusters adjacent to granulomata in human coccidioidomycosis. Infect. Immun. 73:39233928. http://dx.doi.org/10.1128/IAI.73.7.3923-3928.2005.

39. Molloy MJ, Zhang W, Usherwood EJ. 2011. Suppressive CD8 ${ }^{+}$T cells arise in the absence of CD4 help and compromise control of persistent virus. J. Immunol. 186:6218-6226. http://dx.doi.org/10.4049/jimmunol .1003812 .

40. Noble A, Giorgini A, Leggat JA. 2006. Cytokine-induced IL-10-secreting CD8 T cells represent a phenotypically distinct suppressor T-cell lineage. Blood 107:4475-4483. http://dx.doi.org/10.1182/blood-2005-10-3994.

41. Trandem K, Zhao J, Fleming E, Perlman S. 2011. Highly activated cytotoxic CD8 T cells express protective IL-10 at the peak of coronavirusinduced encephalitis. J. Immunol. 186:3642-3652. http://dx.doi.org/10 .4049/jimmunol.1003292.

42. Madan R, Demircik F, Surianarayanan S, Allen JL, Divanovic S, Trompette A, Yogev N, Gu Y, Khodoun M, Hildeman D, Boespflug N, Fogolin MB, Grobe L, Greweling M, Finkelman FD, Cardin R, Mohrs M, Muller W, Waisman A, Roers A, Karp CL. 2009. Nonredundant roles for B cell-derived IL-10 in immune counter-regulation. J. Immunol. 183: 2312-2320. http://dx.doi.org/10.4049/jimmunol.0900185.

43. Schwarz T, Remer KA, Nahrendorf W, Masic A, Siewe L, Muller W, Roers A, Moll H. 2013. T cell-derived IL-10 determines leishmaniasis disease outcome and is suppressed by a dendritic cell-based vaccine. PLoS Pathog. 9(6):e1003476. http://dx.doi.org/10.1371/journal.ppat.1003476.

44. Roers A, Siewe L, Strittmatter E, Deckert M, Schlüter D, Stenzel W, Gruber AD, Krieg T, Rajewsky K, Müller W. 2004. T cell-specific inactivation of the interleukin 10 gene in mice results in enhanced $\mathrm{T}$ cell responses but normal innate responses to lipopolysaccharide or skin irritation. J. Exp. Med. 200:1289-1297. http://dx.doi.org/10.1048/jem .20041789 .

45. Siewe L, Bollati-Fogolin M, Wickenhauser C, Krieg T, Müller W, 
Roers A. 2006. Interleukin-10 derived from macrophages and/or neutrophils regulates the inflammatory response to LPS but not the response to CpG DNA. Eur. J. Immunol. 36:3248-3255. http://dx.doi .org/10.1002/eji.200636012.

46. Viriyakosol S, Jimenez Mdel P, Gurney MA, Ashbaugh ME, Fierer J. 2013. Dectin-1 is required for resistance to coccidioidomycosis in mice. mBio 4(1):e00597-00512. http://dx.doi.org/10.1128/mBio.00597-12.

47. Zhang X, Majlessi L, Deriaud E, Leclerc C, Lo-Man R. 2009. Coactivation of Syk kinase and MyD88 adaptor protein pathways by bacteria promotes regulatory properties of neutrophils. Immunity 31:761-771. http: //dx.doi.org/10.1016/j.immuni.2009.09.016.

48. Viriyakosol S, Fierer J, Brown GD, Kirkland TN. 2005. Innate immunity to the pathogenic fungus Coccidioides posadasii is dependent on Toll-like receptor 2 and Dectin-1. Infect. Immun. 73:1553-1560. http://dx.doi.org /10.1128/IAI.73.3.1553-1560.2005.

49. Bettelli E, Carrier Y, Gao W, Korn T, Strom TB, Oukka M, Weiner HL, Kuchroo VK. 2006. Reciprocal developmental pathways for the genera- tion of pathogenic effector Th17 and regulatory T cells. Nature 441:235238. http://dx.doi.org/10.1038/nature04753.

50. Fierer J, Waters C, Walls L. 2006. Both $\mathrm{CD}^{+}$and $\mathrm{CD} 8^{+} \mathrm{T}$ cells can mediate vaccine-induced protection against Coccidioides immitis infection in mice. J. Infect. Dis. 193:1323-1331. http://dx.doi.org/10.1086/502972.

51. Nanjappa SG, Heninger E, Wuthrich M, Gasper DJ, Klein BS. 2012. Tc17 cells mediate vaccine immunity against lethal fungal pneumonia in immune deficient hosts lacking $\mathrm{CD}^{+} \mathrm{T}$ cells. PLoS Pathog. 8(7): e1002771. http://dx.doi.org/10.1371/journal.ppat.1002771.

52. Rivera A, Collins N, Stephan MT, Lipuma L, Leiner I, Pamer EG. 2009. Aberrant tissue localization of fungus-specific $\mathrm{CD} 4^{+} \mathrm{T}$ cells in IL-10deficient mice. J. Immunol. 183:631-641. http://dx.doi.org/10.4049 /jimmunol.0900396.

53. Sallusto F, Geginat J, Lanzavecchia A. 2004. Central memory and effector memory T cell subsets: function, generation, and maintenance. Annu. Rev. Immunol. 22:745-763. http://dx.doi.org/10.1146/annurev.immunol .22 .012703 .104702 . 